\begin{tabular}{|l|l|l||}
\hline \multicolumn{2}{|c|}{ PublisherInfo } \\
\hline \hline PublisherName & $:$ & BioMed Central \\
\hline \hline PublisherLocation & $:$ & London \\
\hline \hline PublisherImprintName & $:$ & BioMed Central \\
\hline \hline
\end{tabular}

\title{
BLyS in humoral immunity
}

\begin{tabular}{|l|l|l||}
\hline \multicolumn{2}{|c||}{ ArticleInfo } \\
\hline \hline ArticleID & $:$ & 161 \\
\hline \hline ArticleDOI & $:$ & $10.1186 /$ ar-2000-66835 \\
\hline \hline ArticleCitationID & $:$ & 66835 \\
\hline \hline ArticleSequenceNumber & $:$ & 118 \\
\hline \hline ArticleCategory & $:$ & Paper Report \\
\hline \hline ArticleFirstPage & $:$ & 1 \\
\hline \hline ArticleLastPage & $:$ & 3 \\
\hline \hline & & RegistrationDate : 2000-8-29 \\
\hline ArticleHistory & $:$ & OnlineDate \\
\hline \hline ArticleCopyright & $:$ & Current Science Ltd2000-8-29 \\
\hline \hline ArticleGrants & $:$ & \\
\hline \hline ArticleContext & $:$ & 130753311 \\
\hline \hline
\end{tabular}




\section{Keywords}

BAFF, BLyS, germinal, humoral immunity, TACI, TNF ligand superfamily, zTNF4

\section{Context}

The identification and biological actions of a newly described TNF homologue alternatively known as BLyS, BAFF and zTNF4 has generated much interest among immunologists. In previous paper reports, I discussed recent articles describing autoimmune features in BAFF-transgenic mice. A possible role for this molecule in autoimmunity could also be inferred by the presence of high levels of this mediator in murine models of lupus, and a moderate therapeutic effect of the soluble BAFF receptor TACI (transmembrane activator and CAML-interactor) in murine lupus. To study the molecular effects of the molecule and define a role for BLyS in humoral immunity.

\section{Significant findings}

In agreement with previous reports, Yan et al found that the receptor for BLyS was TACI, a previously identified orphan member of the TNF receptor family. Labeled human BLyS bound to cells transfected with a TACI-expression plasmid, and a TACI-Fc fusion protein bound to cells transfected with transmembrane human BLyS. Binding of BLyS to TACI was also confirmed by coimmunoprecipitation experiments. As TNF receptor family members can signal via NF-?B, activation of this transcription factor by BLyS-TACI interaction was studied. Tranfection of TACI alone into cells resulted in little change, while addition of purified BLyS or BLyS co-transfection resulted in significant NF-?B activation. To determine if BLyS-TACI interaction in vivo is important in humoral immune responses, mice were immunized with NP-CGG and treated with TACI-Fc. TACI-Fc significantly inhibited NP-specific IgM and the total and high affinity IgG1 anti-NP antibody responses. No antibody forming cell foci were seen in the splenic periarteriolar lymphoid sheath (PALS) area in treated mice. Furthermore, no germinal centers were present in spleens of TACI-Fc treated mice 14 days after immunization, while splenic follicular architecture was preserved.

\section{Comments}


Interactions between members of the tumor necrosis factor (TNF) ligand superfamily and their receptors play critical roles in T and B cell responses. BLyS is a newly described member of this family; several recent studies have suggested an important role for this molecule in autoimmunity. Furthermore, inhibiting BLyS might also have a therapeutic role in downregulating autoimmune disease. This paper expands on the role of BLyS interacting with its receptor (TACI) in a normal humoral response. Using a fusion molecule of TACI with Fc to inhibit BLyS-TACI interaction facilitated the study of the normal effects of TACI-BLyS engagement. In vitro, BLyS was found to signal via NF-?B activation and increase IgM production in B cells. In a primary immunization model using hapten carrier, BLyS blockade inhibited IgM and IgG anti-hapten antibody responses and germinal center formation. Interesting homologies between the BLyS-TACI and CD40-CD40L systems will no doubt lead to further investigation into possible relationships between these TNF-TNF receptor-like ligand-receptor pairs. The results confirm a critical role for BLyS-TACI interaction in the normal humoral immune response. Interfering with BLyS-TACI interaction using TACI-Fc or a different agent in autoimmune conditions may have therapeutic potential; however, this modality will need to be fine tuned so as to not inhibit the normal protective aspects of the humoral immune response against infection and other foreign antigens.

\section{Methods}

The BLyS receptor was cloned and identified by staining with labeled BLyS cells transfected with cDNAs from a BLyS responsive B cell line. Activation of the transcription factor NF-?B was determined after transfection of the receptor, and stimulation with BLyS. The effects of BLyS-receptor interaction in humoral immunity were tested by treating mice immunized with nitrophenyl-conjugated

chicken gamma globulin (CGG) with the receptor-Fc fusion protein, and following the serum antibody response and splenic histology.

\section{References}

1. Yan M, Marsters SA, Gerwal IS, Wang H, Ashkenazi A, Dixit VM: Identification of a receptor for BLyS demonstrates a crucial role in humoral immunity. Nat Immunol. 2000, 1: 37-40.

This PDF file was created after publication. 